\title{
Teaching /Learning Resources and the Implementation of Agriculture Curriculum in Kakamega Central Sub-County, Kenya
}

\author{
Esther Njeri Kiguthi \\ Department of Curriculum and Instructional and Technology, Masinde Muliro University of Science and \\ Technology \\ Prof. John O. Shiundu \\ Department of Curriculum and Instructional and Technology, Masinde Muliro University of Science and \\ Technology \\ Dr. Eric Wangila \\ Department of Curriculum and Instructional and Technology, Masinde Muliro University of Science and \\ Technology
}

\begin{abstract}
Agriculture is an important base of economic growth and development and source of revenue for many countries and individuals. Teaching of agriculture in schools is one way of ensuring food security and these calls for adequate and relevant teaching-learning resources in schools. This study explored the types and quantities of resources available for the teaching of Agricultures in Kakamega central sub county since enrollment and performance in the subject is on the decline. Descriptive Survey research design was employed in the study with a total population of 440 respondents. Data collected was analyzed using Statistical Package for Social Sciences (SPSS) version 17 for windows. The study established that our schools lack the requisite teaching and learning resources for agriculture curriculum.
\end{abstract}

Keywords: Teaching- learning Resources, Secondary Agriculture

DOI: $10.7176 / \mathrm{JEP} / 10-19-02$

Publication date:July $31^{\text {st }} 2019$

\section{Introduction}

\subsection{Background Information}

Teaching learning resources are the bedrock on which effective and efficient teaching and learning is anchored especially in practical and technical subjects of which Agriculture belongs. Teachers are tasked to select, design and develop the teaching strategy with the available resources.Besides; availability of teaching learning resources has a greater influence on curriculum implementation process. Malcolm (1976) observes that, when these resources are presented raw, they offer stimulating alternative that improves conception.

Egun and Badmus, (2007) noted that Agriculture was taught in the confines of the classrooms theoretically with no practical work and without the use of relevant instructional materials in Nigerian secondary schools. Literature reveals that poor method of teaching leads to negative attitudes towards a subject. It is no wonder that Egun and Badmus (2007) assert that lack of relevant instructional materials is ranked highly as a reason for teachers' difficulty in teaching certain content areas of Agriculture. Besides, learning occurs through interaction with one's environment. The facilities include but not limited to books, audio-visual, software and hardware of educational technology; so also, size of classroom, farm structures and school farms, agricultural clubs availability of tables, chairs, chalkboards and shelves on which instruments for practical's are arranged (Akande, 1985).

\subsection{Statement of the Problem}

Teaching and learning materials directly impact on quality of education as they determine how effectively the curriculum is implemented. The implementation of Agriculture curriculum faces a lot of challenges due to lack of farm tools and machinery(Kenya Institute of Education, 1990). The availability of teaching and learning support materials is among the most important determinants of effectiveness of post - primary agricultural education and training (Vandenbosch, 2006). Essentially, quality education cannot be guaranteed leave alone be sustained if the resources and facilities are not available and in sufficient quantities. This study sought to establish types and adequacy of resources for teaching/learning of Agriculture in public secondary schools in Kakamega Central Sub County and determine how this impact on implementation of Agriculture curriculum. 


\subsection{Study findings and Discussions}

Schools that offer agriculture have the following basic tool that are used to implement agriculture curriculum; forked jembes (31.3\%) Jembes (27.3\%) and Pangas (18.7\%). Agricultural tools are categorized as livestock tools, workshop tools farm tools and farm machinery. From the mentioned tools, most schools are able to provide simple farm tools only that can not adquately augument the implementation of agriculture curriculun. This clearly shows that Agriculture has not received the attention it deserves in terms of funding and consequently impacting on students attitude negatively leading to the decline in enrollment and a drop in performance. Learners therefore percieve the subject as not important, hard and not interesting hence they shy away from it.Agriculture being a practical subject,lack of learning resources puts teachers in a precarious situation as they find it difficult to deliver the content.

This scenario is affirmed the the teachers of agriculture and the school deputy principals who concur that school do not have the requisite tools for teaching high school agriculture. The table 1 reveals the views of deputy principals and teachers regarding the poition of teaching resouses for agriculture in schools.

Table 1: Deputy Principals and Teachers opinion on Agriculture Resource

\begin{tabular}{lcccccccc}
\hline \multirow{2}{*}{ Resources } & \multicolumn{3}{c}{ Teachers } & \multicolumn{3}{c}{ Principals } \\
\cline { 2 - 9 } & \multicolumn{2}{c}{ Yes } & \multicolumn{2}{c}{ No } & \multicolumn{3}{c}{ Yes } & \multicolumn{2}{c}{ No } \\
\cline { 2 - 9 } & F & $\%$ & F & $\%$ & F & $\%$ & F & $\%$ \\
\hline Availability & 5 & 43 & 6 & 57 & 7 & 60 & 4 & 40 \\
Enough & 2 & 14 & 9 & 86 & 2 & 20 & 9 & 80 \\
from the community & 3 & 29 & 8 & 71 & 4 & 40 & 7 & 60 \\
School supplies them & 2 & 14 & 9 & 86 & 4 & 40 & 7 & 60 \\
MOEST supplies & 3 & 29 & 8 & 71 & 4 & 40 & 7 & 60 \\
\hline
\end{tabular}

Results in table1 reveal (60\%) of the Deputy Principals affirm that basic Agriculture resources are available though not adequate. Similarly, $(86 \%)$ of teachersconfirm that agriculture resources are not enough and this makes it very hard for teachers to teach many concepts in the Agriculture syllabus. This has been attributed to the declining enrollment and performance in the subject. Supply of this resourse is not the obligation of the ministry of Education as (71\%) of teachers agree that agriculture resources are obtained from the community.Such resourses include community cattle dips, machinery from local farmers who carry out large scale farming especially of sugarcane and maize.

The only resources MoEsupplies are agriculture textbooks and teachers' Guide books but not tools and equipment.

Participatory observations was employed to confirm or otherwise the above findings. Results in Table 2 presents the status of the resources in sampled schools.

Table 2:Status of Resourses as observed in Sampled schools

\begin{tabular}{lccccccccc}
\hline \hline $\begin{array}{l}\text { Schools } \\
\text { sampled }\end{array}$ & $\begin{array}{c}\text { Text } \\
\text { books }\end{array}$ & $\begin{array}{c}\text { Teaching } \\
\text { aids }\end{array}$ & $\begin{array}{c}\text { Agric } \\
\text { clubs }\end{array}$ & land & Tools & $\begin{array}{c}\text { Agric } \\
\text { lab }\end{array}$ & $\begin{array}{c}\text { Agric } \\
\text { staff }\end{array}$ & Lessons & Timetable \\
\hline A & 2 & 1 & 3 & 3 & 1 & 0 & 1 & 1 & 3 \\
B & 2 & 1 & 3 & 3 & 1 & 0 & 1 & 1 & 3 \\
C & 2 & 1 & 2 & 3 & 1 & 0 & 3 & 1 & 3 \\
D & 2 & 1 & 2 & 1 & 1 & 0 & 1 & 1 & 3 \\
E & 2 & 1 & 2 & 1 & 1 & 0 & 1 & 1 & 3 \\
F & 2 & 1 & 2 & 1 & 1 & 0 & 1 & 1 & 3 \\
G & 2 & 1 & 2 & 1 & 1 & 0 & 1 & 1 & 3 \\
H & 2 & 1 & 2 & 1 & 1 & 0 & 1 & 1 & 3 \\
I & 2 & 1 & 2 & 1 & 1 & 0 & 1 & 1 & 3 \\
J & 2 & 1 & 2 & 1 & 1 & 0 & 1 & 1 & 3 \\
K & 2 & 1 & 2 & 1 & 1 & 0 & 1 & 1 & 3 \\
\hline \hline
\end{tabular}

Rating scale: $3=$ Very adequate $2=$ Adequate $\quad 1=$ Not adequate $\quad 0=$ Not available

Table 2 shows that schools that have adequate textbooks. This may be attributed to the fact that the Government supplies textbooks. Similarly, the teaching aids in the schools arenot adequate but all Young FarmersClubs though majority were inactive. These agrees with Ngesa (2006) who noted that agricultural clubs are a critical ingredient of quality school agriculture in Kenya, however, many students are not engaged in club activities apart from the club serving as a vehicle to attend agricultural shows.

It was also noted that land wasnot adequate in most schools and the little available land was used for form four K.C.S.E agriculture examination projects leaving out students in lower forms to engage in fruitful agricultural projects. The tools and equipment are not adquate in schools but had simple hand tools and equipment like jembes, pangas, spade, wheelbarrow and forked jembes. No school had an agriculture laboratory. The findings confirms Ngesa (2006) assersion that most secondary schools in Kenya lack basic primary crop 
production tools and equipment, livestock tools and farm machinery tools. Most experiences in the classroom occur through verbal symbolism - written and spoken words. These classroom experiences may be easier for teachers to supply, but they may be more difficult for many students to understand. The more senses involved in the learning process, the easier it is for the student to learn.

\subsection{Summary of the Findings}

The study found out that there were enough textbooks and guide books as they were provided by the government but no reference books for extra studies. Another important revelation from the study was the fact that inadequate TLR(s) hinders effective teaching and learning of Agriculture. This situation often makes it difficult for teachers to take students through practical work. Students only learn names of tools and their uses without having a feel of the tool and how to handle it. Seawell (1990) and Bilgin (2006) confirm that without adequate pieces of apparatus, Agriculture and Science lesson would become rigid, boring, dull and unrealistic. The uniqueness of the subject therefore results from the variety of materials and experiment necessary for its effective teaching and learning. Nacino-Brown et al. (1982) also has it that the mere use of these materials however does not guarantee effective teaching and communication. It is their careful selection and skilful handling by the teacher that renders them useful in facilitating learning.

\subsection{Conclusion}

Agriculture as a practical subject should be taught as such and therefore all the relevant teaching/learning resources need to be supplied in all secondary schools by the government. This will ensure equity distribution to all schools and consequently guaranteed implementation of Agriculture curriculum. Inadequacies of teaching/learning resources have impacted negatively Agriculture curriculum implementation, leading to low enrollment and poor performance of the few that enroll in the subject. Agriculture is the mainstay of Kenya's economy and even the 'big-four agenda' of the current government will certainly be achieved majorly through agriculture. It's therefore prudent that the government allocates the lion's share of her resources to equipping of teaching/learning of agriculture at all levels, to ensure high enrollment and consequently a high skilled population in agriculture for great economic growth.

\section{References}

Waldman, M. (2003). Fresher's use of library electronic resources and self-efficacy. Information Research.

Todd, R. A. (2005). Student learning through Ohio school libraries, Part 1: How effective school libraries help students. School Libraries Worldwide.

Ngesa, F.U. (2006). Demand Profiles and Supply Responses for Agricultural Education and Training at the Post Primary Education Level. Nairobi: Unpublished Report.

Mwiria, K. (2005). Vocationalisation of Secondary Education. Nairobi- Kenya: Kenya Literature Bureau Press.

Kipkemei, E. (2001). Contribution of Secondary School Agriculture Knowledge to Rural Agricultural Productivity: The Case of Small Scale Farmers in UasinGichu District. Kenya: Unpublished Project.

Republic of Kenya (1988). Report of National Committee on Educational Objectives and policies - Gachathi Report. Nairobi: Government Printers.

Kathuri, N.J. ( 1996). Prospects and Problem in Secondary Schools Agriculture Education Programme. Nairobi: Bureau of Education Research Kenyatta University. 